\title{
Work motivation and job satisfaction among health workers of primary health facilities: a mixed- methods study from Nepal
}

\section{Pratik Khanal}

Tribhuvan University Institute of Medicine https://orcid.org/0000-0002-1057-5700

Bishnu P Choulagai ( $\square$ bchoulagai@iom.edu.np )

Tribhuvan University https://orcid.org/0000-0002-5418-0380

Pawan Acharya

Nepal Development Society, Chitwan, Nepal

\section{Sharad Onta}

Tribhuvan University Institute of Medicine

\section{Research}

Keywords: Human resources for health, health workers, work motivation, job satisfaction, primary health facility, Nepal

Posted Date: July 16th, 2020

DOI: https://doi.org/10.21203/rs.3.rs-30776/v2

License: (c) (i) This work is licensed under a Creative Commons Attribution 4.0 International License. Read Full License 


\section{Abstract}

Background Work motivation and job satisfaction are linked with the performance and retention of health workforce. Primary health facilities, mostly comprising of mid-level health workers, serve majority of the population in Nepal. The aim of the study was to assess the determinants of job satisfaction in relation to socio-demographics, job characteristics and work motivation status among health workers working in primary health facilities.

Methods A mixed-methods study was conducted in Jhapa district in Eastern Nepal covering 40 primary health facilities. The data collection involved 151 self-administered questionnaire interviews and 16 indepth interviews with the health workers. Mean differences in work motivation among those satisfied and unsatisfied with their job was examined using t tests. Logistic regression with $95 \%$ confidence interval at $p<0.05$ was used for identifying associated factors with job satisfaction. Thematic analysis was done for qualitative data.

Results Among the study participants, $78.2 \%$ were either auxiliary health workers or auxiliary nurse midwives. The median employment period of health workers was 174 months. In the likert scale of five points, the mean score of work motivation was highest for team work (3.99) and lowest for financial motivation (2.21). Age of health workers and satisfaction with career development, and financial motivation were significantly associated with job satisfaction. The qualitative findings also revealed that majority of the health workers were not satisfied with the existing career development opportunities, availability of resources in health facility and financial motivation.

Conclusions Dissatisfaction with career development and financial motivation was significantly associated with lower odds of job satisfaction among health workers. Additionally, resource availability in health facility, recognition of work and management support affected job satisfaction. A focus on improving work environment through increased financial motivation and career development opportunities as well as investing in primary health facilities with increased resource support is recommended to improve job satisfaction.

\section{Background}

Human Resource for Health (HRH) is one of the six building blocks of health system [1] and is considered a strategic capital and input to attain health outcomes [2]. Developing countries face shortage of HRH both geographically and professionally, and their health system is largely supported by mid-level heath workers. Further, skill mix imbalance, inadequate competency, migration and deployment, and performance and retention related issues are major HRH problems in developing countries[3] .

Work motivation and job satisfaction are related but different things which affect the performance of health workers [4]. Work motivation is affected by extrinsic and intrinsic factors [5] and financial factors alone are not sufficient to motivate health workers [6,7]. Job satisfaction improves retention and is achieved by improving working conditions, participation in decision making, responsibility for work, 
supportive leadership and management and professional development [4]. Though both job satisfaction and motivation cannot be directly observable, they are critical to the retention and performance of health workers $[8,9]$.

Nepal is a country among 57 global and six South East Asia Region (SEAR) nations [6]with critical shortage of HRH [10]. Nepal has only 0.17 physicians and 0.50 nurses per 1000 population and the health workforce mainly comprises of non-clinical supporting personnel $(37.65 \%)$ and paramedical practitioners (18.16\%) [11]. Primary health facilities comprise of 198 Primary Health Centers (PHCs) and 3808 Health Posts (HPs) throughout the country and are based in community level[12]. The PHCs have sanctioned post for one medical doctor, one staff nurse, one lab personnel and paramedical practitioners while HPs have paramedical practitioners only[13]. The paramedical practitioners include Health Assistants (HAs), Auxiliary Health Workers (AHWs) and Auxiliary Nurse Midwives (ANMs). The vocational training period of HAs, AHWs and ANMs includes 36 months, 15 months and 18 months, respectively. Similarly, staff nurses and medical laboratory technician had a three-year of training each in their respective areas. There are also cadres like Village Health Workers (VHWs) and Maternal and Child Health Workers (MCHWs) who are responsible for community-based services in the area of maternal and child health including immunization, and reproductive health.

Before the implementation of federalism in 2017, District Public Health Offices (DPHOs) had central role in managing primary health facilities, which are now overseen by local governments with the technical support from health offices in district level[14]. Health workers working in primary health facilities cater to the need of majority of people. The performance of health workers depends on their work motivation and job satisfaction. There is inadequate evidence to guide performance management of health workers in Nepal and other similar settings $[15,16]$. Though several studies have been conducted on motivation and job satisfaction in other developing countries [6], very little is known about health workers of Nepal. Similarly, job satisfaction of those working in primary health facilities are often missed out from such studies. This study addresses the research gap by identifying the determinants of job satisfaction of health workers working in primary health facilities. The evidence will be useful for informing human resource management policy in Nepal and other countries that share similar settings.

\section{Methods}

\section{Study design and setting}

This was a health facility based mixed-methods study conducted in Jhapa district in the Eastern Nepal. Jhapa district was chosen because health sector performance of the district ranked in average among 75 districts of Nepal. Concurrent triangulation method was adopted to triangulate the findings from quantitative and qualitative data. According to the census of 2011, the district had a population of 812,650[17]. There were 246 health 
workers in 50 primary health facilities (six PHCs and 44 HPs) in Jhapa. Additionally, Jhapa has one secondary hospital, as well as private sector hospitals and clinics.

\section{Sampling and study participants}

Among the total six PHCs and 44 HPs, 5 PHCs and 35 HPs were randomly selected. The study participants included all the health workers working in the selected health facilities at the time of study.

\section{Study tools}

For quantitative study, a structured self-administered questionnaire was used comprising of three sections (i) socio-demographic characteristics and job related information; (ii) 21 likert scale items under seven domains to measure work motivation and (iii) one item questionnaire to measure job satisfaction. Since, no tool was developed for specific context, the tool to measure work motivation was developed based on motivational theories [5, 18-20] and earlier work done by Li L et al [21] and Willis-Shattuck M et al. [6]. Based on Herzberg's two factor theory of work motivation[19, 20], seven domains were identified to measure work motivation. Three domains namely recognition, responsibility and career development were related to motivators or intrinsic factors while four domains namely organization and management support, financial motivation, team support, and resource availability were related to extrinsic factors. We included 21 items under these domains. The Cronbach's alpha was calculated 0.72 which was considered sufficient for consistency[22].

The 21 items of work motivation were grouped across seven domains: career development (three items), recognition (three items), responsibility (three items), financial motivation (two items), organization and management support (four items), availability of resources (two items) and team support (four items). Study participants were asked to indicate their level of work motivation on a five-point likert scale: strongly disagree (1), disagree (2), neither agree nor disagree (3), agree (4) and strongly agree (5). Job satisfaction was the outcome variable and assessed on a four-point Likert scale: strongly dissatisfied (1), 
dissatisfied (2), satisfied (3) and strongly satisfied (4). Extensive literature review, pretesting of the tool and consultation with subject experts was done to refine the tool. Guideline was provided to the study participants for filling self-administered questionnaire. To minimize the response bias, balance of negatively worded questions was maintained in Likert scale items.

\section{Data collection}

Before data collection, we conducted a meeting with the respective in-Charges and health workers of the selected health facilities to share study objectives and seek permission. The questionnaire was distributed to health workers in their office at the early office hours and filled questionnaires were collected the same day or the next day. A total of 151 out of 175 health workers (86.3\%) completed the questionnaire. In-depth interviews were conducted concurrently and included in-depth interview with 16 health workers who were selected purposively including different professional categories - one District Public Health Officer, two health assistants, two staff nurses, two ANMs and nine AHWs.

For qualitative study, in-depth interviews were conducted using interview guideline. Exploration with health workers was done on the motivating factors present in the job, job satisfaction status and actions required to improve work motivation and job satisfaction. Data collection was done during January - March in 2016.

\section{Data management and analysis}

Data entry was done in EpiData (version 3.1) and were analyzed using IBM SPSS Statistics 20. Descriptive statistics were presented as frequencies, percentages, mean and median. Work motivation for individual items and each domain was determined by mean value and standard deviation. In case of domains of work motivation, the value equal to or above the mean score was categorized as 'satisfied' and those below as 'not satisfied'. The difference in work motivation among participants those who were or who were not satisfied with their job were assessed by independent t-test. Chi-square test was done to observe the association between categorical independent variables and categorical dependent variable. Thereafter, those variables significant in bivariate analysis were fitted in logistic regression 
model to measure the predictors of job satisfaction. To check collinearity, we calculated the variance inflation factor (VIF) and detected no problem among the independent variables (highest, VIF, 2.02) that would bar their inclusion in analysis. Both unadjusted and adjusted Odds Ratio (OR) were calculated. Statistical significance was set at $\mathrm{p}<0.05$.

The in-depth interviews were transcribed from audio scripts and then translated from Nepali into English. Transcripts were studied and analyzed under three main themes (Table $1)$.

Table 1 Themes and categories for data analysis.

\begin{tabular}{|l|l|}
\hline Themes & Categories \\
\hline $\begin{array}{l}\text { Work motivation of health } \\
\text { workers }\end{array}$ & $\begin{array}{l}\text { Motivation to do work, hindrances to work motivation, } \\
\text { factors affecting work motivation }\end{array}$ \\
\hline $\begin{array}{l}\text { Actions required to } \\
\text { improve work motivation }\end{array}$ & $\begin{array}{l}\text { Role of local government, DPHO and ministry of health and } \\
\text { population }\end{array}$ \\
\hline $\begin{array}{l}\text { Job satisfaction among } \\
\text { health workers }\end{array}$ & $\begin{array}{l}\text { Satisfaction with the job, satisfaction with the working } \\
\text { conditions, current problems in profession }\end{array}$ \\
\hline
\end{tabular}

\section{Ethical considerations}

Written informed consent was obtained from the research participants prior to the data collection. Participants were assured of confidentiality of their information by explaining the objectives of the study and the use of information for the study purpose. Study participants were informed clearly about their freedom to opt out of the study at any point of time without providing justification for doing so. Ethical approval was obtained from Institutional Review Board of Institute of Medicine, Tribhuvan University, Kathmandu (Reference number: 159/2016).

\section{Results}


The median age of the study participants was 38 years and $50.3 \%$ were male. Ethnicity wise, $70.2 \%$ of health workers belonged to Brahmin/Chhetri group. Most of the health workers were AHWs (41.1\%) and ANMs (37.1\%). The median period of employment in government service and current health facility was 174 months (IQ range: 80-228 months) and 25 months (IQ range: 10-86 months) respectively. Majority of the health workers (86.8\%) held permanent jobs. Similarly, $41.1 \%$ of health workers had alternative source of income among which $61.9 \%$ were engaged in private practice in clinics whereas $28.6 \%$ pursued agriculture to supplement their income. (Table 2).

Table 2 Socio-demographic and job related characteristics of the participant $(n=151)$ 


\begin{tabular}{|c|c|c|}
\hline Variables & Frequency & Percentage \\
\hline \multicolumn{3}{|c|}{ Age (IQ range: 32-44 years) } \\
\hline $20-29$ & 29 & 19.2 \\
\hline $30-39$ & 58 & 38.4 \\
\hline 40 and above & 64 & 42.4 \\
\hline \multicolumn{3}{|l|}{ Sex } \\
\hline Male & 76 & 50.3 \\
\hline Female & 75 & 49.7 \\
\hline \multicolumn{3}{|l|}{ Ethnicity } \\
\hline Brahmin/Chhetri & 106 & 70.2 \\
\hline Janajati & 22 & 14.6 \\
\hline Madheshi & 19 & 12.6 \\
\hline Muslim & 2 & 1.3 \\
\hline Dalit & 2 & 1.3 \\
\hline \multicolumn{3}{|l|}{ Type of Health Facility } \\
\hline $\mathrm{HP}$ & 119 & 78.8 \\
\hline PHC & 32 & 21.2 \\
\hline \multicolumn{3}{|l|}{ Professional category } \\
\hline Sr. AHW and AHW & 62 & 41.1 \\
\hline Sr. ANM and ANM & 56 & 37.1 \\
\hline Health Assistant & 12 & 7.9 \\
\hline Lab Assistant & 12 & 7.9 \\
\hline Staff Nurse & 5 & 3.3 \\
\hline Medical Officer & 4 & 2.7 \\
\hline \multicolumn{3}{|l|}{ Type of service } \\
\hline Permanent & 131 & 86.8 \\
\hline Temporary & 20 & 13.2 \\
\hline \multicolumn{3}{|l|}{ Position level } \\
\hline Assistant & 85 & 56.3 \\
\hline Officer & 66 & 44.7 \\
\hline \multicolumn{3}{|l|}{ Working in home district } \\
\hline Yes & 117 & 77.5 \\
\hline \multicolumn{3}{|c|}{ Higher qualification other than health science } \\
\hline Yes & 67 & 44.4 \\
\hline \multicolumn{3}{|c|}{ Alternative Source of income } \\
\hline Yes & 63 & 41.1 \\
\hline \multicolumn{3}{|c|}{ Source of alternative income $(n=63)$} \\
\hline Have own private clinic & 39 & 61.9 \\
\hline Agriculture & 18 & 28.6 \\
\hline Others & 6 & 9.5 \\
\hline
\end{tabular}

IQ, interquartile range 
The mean score of work motivation for individual items was higher for 'team work' (4.17), 'relationship between co-workers' (4.15), and 'clear work roles' (3.97) while it was lower for 'training' (1.90), 'available equipment' (2.10) and 'salary' (2.13) (Table 3).

Work motivation as per domains was higher for team work (3.99) and responsibility (3.50) while it was lower for financial motivation (2.21) and career development (2.41). Work motivation was higher among health workers who were satisfied with their job than those not satisfied across all domains except availability of resources (Table 4).

Table 3 Mean scores of individual items of motivation 


\begin{tabular}{|c|c|c|c|c|}
\hline Item & Motivation items & Domain & Mean & SD \\
\hline 12 & $\begin{array}{l}\text { I enjoy the team with which I work at the health } \\
\text { facility }\end{array}$ & Team work & 4.17 & 0.67 \\
\hline 15 & $\begin{array}{l}\text { There is a good relationship between co-workers in } \\
\text { my health facility }\end{array}$ & Team work & 4.15 & 0.68 \\
\hline 16 & $\begin{array}{l}\text { Everyone working in the health facility have clear } \\
\text { work roles. }\end{array}$ & Team work & 3.97 & 0.83 \\
\hline 5 & $\begin{array}{l}\text { I am happy with the amount of responsibility I am } \\
\text { given. }\end{array}$ & Responsibility & 3.95 & 0.98 \\
\hline 14 & $\begin{array}{l}\text { There is a good collaboration between my facility } \\
\text { and District Public health Office. }\end{array}$ & $\begin{array}{l}\text { Organization } \\
\text { and } \\
\text { management } \\
\text { support }\end{array}$ & 3.89 & 0.74 \\
\hline 13 & $\begin{array}{l}\text { I have a role while taking important decisions } \\
\text { about the health facility where I work. }\end{array}$ & Responsibility & 3.74 & 1.01 \\
\hline 2 & $\begin{array}{l}\text { I feel that the work I do is not appreciated by the } \\
\text { community. a }\end{array}$ & Recognition & 3.72 & 1.02 \\
\hline 19 & $\begin{array}{l}\text { Female Community Health Volunteers are doing a } \\
\text { good job }\end{array}$ & Team work & 3.66 & 0.97 \\
\hline 21 & $\begin{array}{l}\text { Health is a priority of this Village Development } \\
\text { Committee/Municipality }\end{array}$ & $\begin{array}{l}\text { Organization } \\
\text { and } \\
\text { management } \\
\text { support }\end{array}$ & 3.45 & 1.08 \\
\hline 11 & $\begin{array}{l}\text { Supervision from District health Office is in a } \\
\text { supportive manner. }\end{array}$ & $\begin{array}{l}\text { Organization } \\
\text { and } \\
\text { management } \\
\text { support }\end{array}$ & 3.17 & 1.11 \\
\hline 20 & $\begin{array}{l}\text { My suggestions for the improvement of the health } \\
\text { facility are not taken seriously by health facility in } \\
\text { charge/District Public Health Office }\end{array}$ & $\begin{array}{l}\text { Organization } \\
\text { and } \\
\text { management } \\
\text { support }\end{array}$ & 3.13 & 0.99 \\
\hline 18 & $\begin{array}{l}\text { There are enough staffs to provide quality care in } \\
\text { the health facility. }\end{array}$ & $\begin{array}{l}\text { Availability of } \\
\text { resources }\end{array}$ & 2.97 & 1.25 \\
\hline 17 & $\begin{array}{l}\text { I do not get the opportunity to use my abilities at } \\
\text { work. }^{\text {a }}\end{array}$ & Responsibility & 2.84 & 1.26 \\
\hline 8 & $\begin{array}{l}\text { When I do a good job, I receive recognition from } \\
\text { District Public Health Office for my work. }\end{array}$ & Recognition & 2.78 & 1.22 \\
\hline 1 & $\begin{array}{l}\text { I am satisfied with the government's policy for } \\
\text { further education for its employees. }\end{array}$ & $\begin{array}{l}\text { Career } \\
\text { development }\end{array}$ & 2.66 & 1.43 \\
\hline 7 & $\begin{array}{l}\text { Opportunity for promotion in the health service is } \\
\text { so frustrating. }{ }^{a}\end{array}$ & $\begin{array}{l}\text { Career } \\
\text { development }\end{array}$ & 2.53 & 1.30 \\
\hline
\end{tabular}




\begin{tabular}{|l|l|l|l|c|}
\hline 3 & $\begin{array}{l}\text { Apart from salary, i am satisfied with the incentives } \\
\text { i get. }\end{array}$ & $\begin{array}{l}\text { Financial } \\
\text { motivation }\end{array}$ & 2.30 & 1.22 \\
\hline 9 & $\begin{array}{l}\text { There are too few rewards for those who work at } \\
\text { primary health facilities. }^{\text {a }}\end{array}$ & Recognition & 2.15 & 1.12 \\
\hline 6 & Remuneration for my job is adequate. & $\begin{array}{l}\text { Financial } \\
\text { motivation }\end{array}$ & 2.13 & 1.17 \\
\hline 10 & $\begin{array}{l}\text { The equipments in my working station are adequate } \\
\text { and in good working condition. }\end{array}$ & $\begin{array}{l}\text { Availability of } \\
\text { resources }\end{array}$ & 2.10 & 0.97 \\
\hline 4 & $\begin{array}{l}\text { There are limited training opportunities for health } \\
\text { personnel working in the community. }\end{array}$ & $\begin{array}{l}\text { Career } \\
\text { development }\end{array}$ & 1.90 & 0.96 \\
\hline
\end{tabular}

a denotes negative statements and has been reversed during analysis

Table 4 Mean score of the overall perception and domains of work motivation with respect to job satisfaction level

\begin{tabular}{|c|c|c|c|c|}
\hline \multirow[t]{2}{*}{ Work motivation } & \multirow{2}{*}{$\begin{array}{l}\text { Mean } \pm \text { SD } \\
\text { Total } \\
(n=151)\end{array}$} & \multicolumn{2}{|c|}{ Job Satisfaction } & \multirow{2}{*}{$\begin{array}{l}\text { p-value } \\
\mathrm{b}\end{array}$} \\
\hline & & $\begin{array}{l}\text { Not-Satisfied } \\
(n=36,23.8 \%)\end{array}$ & $\begin{array}{l}\text { Satisfied } \\
(\mathrm{n}=115,76.2 \%)\end{array}$ & \\
\hline Over all perception & $3.11 \pm 0.48$ & $2.74 \pm 0.51$ & $3.23 \pm 0.40$ & $<0.001$ \\
\hline Team work & $3.99 \pm 0.56$ & $3.79 \pm 0.65$ & $4.05 \pm 0.51$ & 0.015 \\
\hline Responsibility & $3.50 \pm 0.70$ & $2.93 \pm 0.86$ & $3.69 \pm 0.59$ & $<0.001$ \\
\hline $\begin{array}{ll}\text { Organization } & \text { and } \\
\text { Management Support } & \end{array}$ & $3.41 \pm 0.67$ & $3.03 \pm 0.81$ & $3.53 \pm 0.58$ & $<0.001$ \\
\hline Recognition & $2.88 \pm 0.67$ & $2.64 \pm 0.77$ & $2.96 \pm 0.66$ & 0.016 \\
\hline Availability of resources & $2.53 \pm 0.87$ & $2.33 \pm 0.77$ & $2.60 \pm 0.90$ & 0.115 \\
\hline Career development & $2.36 \pm 0.88$ & $1.86 \pm 0.72$ & $2.52 \pm 0.87$ & $<0.001$ \\
\hline Financial & $2.21 \pm 0.97$ & $1.67 \pm 0.86$ & $2.39 \pm 0.94$ & $<0.001$ \\
\hline
\end{tabular}

$\mathrm{b}$ Independent samples t-test was computed with $\mathrm{p}$ value less than 0.05 considered as statistically significant

\section{Factors associated with job satisfaction}

Overall, $7.9 \%$ were very satisfied with their job and $68.2 \%$ were satisfied with their job. Similarly, $1.3 \%$ of health workers were very dissatisfied with their job and $22.5 \%$ were 
dissatisfied with their job (Table not shown).

In the bivariate analysis, age and time period of employment was significantly associated with job satisfaction while sex, ethnicity, professional category, educational qualification, position, type of health facility, working in home district and alternative income were not significantly associated with job satisfaction. Among seven motivation domains, availability of resources was not significantly associated with job satisfaction ( $p>0.05$ ) while all other domains of work motivation were significantly associated $(p<0.05)$. Overall motivation level was also statistically significant with job satisfaction $(p<0.001)$.

Those factors which were significantly associated with job satisfaction in the bivariate analysis $(\mathrm{p}<0.05)$ were included in the multivariate model. Multiple logistic regression analysis found, after adjusting the effect of age, duration of employment and work motivation domains, health workers of age 40-59 years (AOR=6.75, 95\% CI: 1.25-36.45) were significantly more likely to be satisfied than 20-29 years. Similarly, health workers who were not satisfied with career development (AOR=0.20, 95\% CI: 0.06-0.62 -) and financial motivation $(\mathrm{AOR}=0.33,95 \% \mathrm{CI}=0.11-0.99)$ had significantly lower odds of job satisfaction as compared to those who were satisfied (Table 5).

Table 5 Factors associated with job satisfaction 


\begin{tabular}{|c|c|c|c|c|}
\hline \multirow[t]{2}{*}{ Variables } & \multicolumn{2}{|c|}{$\begin{array}{c}\text { Job Satisfaction } \\
\text { N (\%) } \\
\end{array}$} & \multirow[t]{2}{*}{$\begin{array}{l}\text { Crude OR } \\
(95 \% \mathrm{CI})\end{array}$} & \multirow[t]{2}{*}{$\begin{array}{l}\text { Adjusted OR } \\
(95 \% \mathrm{CI})\end{array}$} \\
\hline & $\begin{array}{l}\text { Yes } \\
(\mathrm{n}=115)\end{array}$ & \begin{tabular}{|l|} 
No \\
$(\mathrm{n}=36)$
\end{tabular} & & \\
\hline \multicolumn{5}{|l|}{ Age } \\
\hline $20-29$ & $17(58.6)$ & $\begin{array}{l}12 \\
(41.4)\end{array}$ & Ref & Ref \\
\hline $30-39$ & $41(70.7)$ & \begin{tabular}{|l|}
17 \\
$(29.3)$ \\
\end{tabular} & $\begin{array}{ll}1.70 & (0.67- \\
4.32) & \\
\end{array}$ & $\begin{array}{ll}2.19 & (0.62- \\
7.32) & \\
\end{array}$ \\
\hline 40 and above & $57(89.1)$ & $7(10.9)$ & $\begin{array}{ll}5.75 & (1.96- \\
16.89) & \\
\end{array}$ & $\begin{array}{ll}6.75 & (1.25- \\
36.45) & \\
\end{array}$ \\
\hline \multicolumn{5}{|c|}{ Time period of employment } \\
\hline $0-15$ years & $52(68.4)$ & $\begin{array}{l}24 \\
(31.6)\end{array}$ & Ref & Ref \\
\hline$>15$ years & $63(84.0)$ & \begin{tabular}{|l|}
12 \\
$(16.0)$ \\
\end{tabular} & $\begin{array}{ll}2.42 & (1.11- \\
5.31) & \\
\end{array}$ & $\begin{array}{ll}1.16 & (0.34- \\
3.94) & \\
\end{array}$ \\
\hline \multicolumn{5}{|c|}{ Career development } \\
\hline Not satisfied & $57(64.8)$ & \begin{tabular}{|l|}
31 \\
$(35.2)$
\end{tabular} & $\begin{array}{ll}0.16 & (0.06- \\
0.44) & \end{array}$ & $\begin{array}{ll}0.20 & (0.06- \\
0.62) & \end{array}$ \\
\hline Satisfied & $58(92.1)$ & $5(7.9)$ & Ref & Ref \\
\hline \multicolumn{5}{|l|}{ Recognition } \\
\hline Not satisfied & $47(68.1)$ & \begin{tabular}{|l|}
22 \\
$(31.9)$
\end{tabular} & $\begin{array}{l}0.44(0.20- \\
0.95)\end{array}$ & $\begin{array}{l}0.57(0.22- \\
1.47)\end{array}$ \\
\hline Satisfied & $68(82.9)$ & \begin{tabular}{|l|}
14 \\
$(17.1)$
\end{tabular} & Ref & Ref \\
\hline \multicolumn{5}{|l|}{ Responsibility } \\
\hline Not satisfied & 43 (63.2) & \begin{tabular}{|l|}
25 \\
$(36.8)$
\end{tabular} & $\begin{array}{l}0.26(0.12- \\
0.59)\end{array}$ & $\begin{array}{l}1.78(0.68- \\
4.69)\end{array}$ \\
\hline Satisfied & $72(86.7)$ & \begin{tabular}{|l|}
11 \\
$(13.3)$ \\
\end{tabular} & Ref & Ref \\
\hline \multicolumn{5}{|l|}{ Financial } \\
\hline Not satisfied & $60(66.7)$ & \begin{tabular}{|l|}
30 \\
$(33.7)$
\end{tabular} & $\begin{array}{l}0.22(0.08- \\
0.56)\end{array}$ & $\begin{array}{l}0.33(0.11- \\
0.99)\end{array}$ \\
\hline Satisfied & $55(90.2)$ & $6(9.8)$ & Ref & Ref \\
\hline \multicolumn{5}{|c|}{$\begin{array}{l}\text { Organizational and management } \\
\text { Support }\end{array}$} \\
\hline Not satisfied & $40(64.5)$ & \begin{tabular}{|l|}
22 \\
$(35.5)$
\end{tabular} & $\begin{array}{l}0.34(0.16- \\
0.74)\end{array}$ & $\begin{array}{l}1.12(0.40- \\
3.12)\end{array}$ \\
\hline Satisfied & $75(84.3)$ & \begin{tabular}{|l|}
14 \\
$(15.7)$ \\
\end{tabular} & Ref & Ref \\
\hline \multicolumn{5}{|l|}{ Team Support } \\
\hline Not satisfied & $28(59.6)$ & \begin{tabular}{|l|}
19 \\
$(40.4)$
\end{tabular} & $\begin{array}{l}0.29(0.13- \\
0.63)\end{array}$ & $\begin{array}{l}0.50(0.19- \\
1.34)\end{array}$ \\
\hline Satisfied & 87 (83.7) & \begin{tabular}{|l|}
17 \\
$(16.3)$
\end{tabular} & Ref & Ref \\
\hline
\end{tabular}


* Significant at $\mathrm{p}$ value $<0.05$

Findings from the in-depth interview

Work motivation status among health workers

\section{Career development}

Majority of the health workers mentioned that inadequate career development opportunities affected their work motivation. Unpaid study leave and lack of reservation for public sector health workers in the academic institutions were identified as hindrance for further education and promotion. Similarly, selection for training opportunity did not consider equity, young age and performance.

'The government does not let us develop our skills and it does not promote to higher position. Those who want to study will have to take unpaid leave. Who will study in this environment?' [Health assistant]

\section{Availability of resources}

Majority of the health workers mentioned that their health facilities lacked adequate resources mainly proper infrastructure and, necessary medicines and equipment. Inadequate availability of resources has decreased public trust on primary health facilities, and hence affected their work motivation.

'We demand for medicines and equipments but there is no timely supply from the district public health office. We have to bear the complaints of the public'. [Staff nurse]

'The government is busy with announcements like hypertension drugs will be given for free. But the government does not see the shortage of drugs. We have to give answers to the public that we don't have sufficient drugs.' [AHW]

\section{Financial factor}


Most of the health workers perceived that current remuneration was inadequate to meet their living expenses including child care and education, and suggested revision based on the market rises.

'Government provides low salary, does not promote us and does not take care of our further education. Then, how shall we be accountable for the government? Only if health workers are staying is because of their private clinics.' [Health Assistant]

"Financial motivation is low for health workers. However, increasing salary alone will not help to increase stay of health workers in health facilities unless proper code of conduct for health workers are made and implemented". [District Public Health Officer]

\section{Recognition}

Some health workers were dissatisfied with the higher authorities due to lack of proper recognition of their work. They complained that performance of health workers was not assessed and reward system was non-functional. They however expressed happiness with the support received from the community people.

'There is no appreciation and encouragement from the DPHO. Performance of health workers is not assessed. What cost will it take to give a certificate to recognize the work done by us?'[AHW]

\section{Management support}

Health workers demanded the need of regular supervision and feedback system, evaluation of performance, availability of office operation expenses and encouragement from the DPHO.

'Health system in district level is running as it is. Through review meeting, we are given feedback but this does not help much'. [AHW]

Besides mentioned above, the other factors that affected work motivation was low priority given to the health sector by the local governments, trade union politics in case of transfer 
and those close to power receiving training opportunities, and seniority row between health assistant and Sr. AHW in taking leadership of the health facility.

In qualitative analysis, permanent nature of the job was perceived as a factor for job satisfaction. However, health workers expressed that there was inadequate investment of government in primary health facilities and the government was focusing only on the health indicators and not on the health system issues. Moreover, they were burdened with administrative works. They also expressed dissatisfaction with the transfer system and government attention towards health workers working in primary health facilities.

'If there is anything to motivate about the job, it is the permanent job. Once you enter into the service, it will be difficult to leave the job. Only ambitious people leave their job. In our context, at least for paramedics, very few leave their job'. [Health Assistant]

\section{Discussion}

Higher age, career development and financial motivation were the determining factors of job satisfaction in our study population. Motivational score was the lowest for financial motivation. The qualitative findings also identified that the existing remuneration was inadequate to cover health worker's living expenses including schooling for their children. A significant proportion of service providers in our study worked in private clinics for additional income. This shows that health workers perceived that the existing salary and incentives were inadequate. Financial factor has been reported of associated with job satisfaction in studies around the world including China [21], Kenya[23], Ethiopia[24] and South Africa [25]. As remuneration is linked with meeting personal and family needs, we suggest the government for salary adjustment of health workers to improve job satisfaction.

In this study, career development was associated with job satisfaction which are in line with previous studies conducted in Nepal[15,26]. Unpaid leave and lack of quotas for government staffs for further studies has affected the career ladder for these health workers. Interestingly, there are government quotas only for pursuing post-graduate studies which has hampered the professional growth of mid-level health workers. Health workers perceived training opportunity as scarce and not equitable in our study which was similar to the finding from a previous study done in Nepal in 2012[27]. Inadequate career development opportunities affects the job satisfaction and ultimately the performance of health workers and health system as a whole which are supported by previous studies done in Nepal[28], India[29], Pakistan[30] and Ethiopia[24]. We thus suggest the need of in-service interventions such as further education and training opportunities for health workers working in primary health facility settings. Health workers of older age were more satisfied than younger health worker in our study which might be due to 
less expectation as compared to younger ones. Studies from China[21], Cyprus[31] and Nepal[26] showed similar findings while younger health workers were more satisfied in Ethiopia [32].

The HRH in primary health facilities are the major service providers for rural Nepal. This is also true for other developing countries including Tanzania, Malawi and South-Africa [33]. The job satisfaction of these cadres is essential for obtaining desired health outcomes especially because specialized health workforce like doctors are scarce and are more likely to work in private hospitals[11], urban areas or migrate to foreign countries because of limited opportunities [34,35]. Health workers of primary health facilities stayed longer in the job. Similar phenomena were observed in Tanzania and Malawi where health workers worked for more than 10 years in their position [33]. They are less likely to migrate to other countries too because of the permanent nature of the job and non-transferable degree which is better suited to the local context [3].

Nepal's National Health Policy 2019[36] has identified further education, in-service training and professional development opportunities for HRH development. However, little is focused when it comes to improving the working conditions and providing management support[37] and it is more pronounced in primary health facilities and its health workers where the burden of health system lies [38]. Lack of formal motivation scheme can leave these health workers abandoned [39]. A motivated and satisfied health workforce is thus crucial to attaining policy objectives and efforts should be made to design interventions taking into account the contextual realities of the country. In the context of federal governance in Nepal, provincial and local governments (municipalities) can play an important role for addressing HRH issues with focus on financial and non-financial motivation, and distribution [40, 41].

Additionally, from the qualitative study, health workers perceived inadequate availability of resources as factors affecting their work motivation. Health workers were not satisfied with the infrastructure, shortage of drugs, equipments and supplies, which in turn has affected community trust on them. This spells out the need of investing in primary health facilities for improving work environment and work morale of health workers, and increasing community trust. The study findings are in accordance with the published research in developing countries suggesting that the identified issues are genuine and demand appropriate interventions.

\section{Strengths and limitations}

This paper provides a comprehensive perspective regarding the effect of socio-demographics and work motivation on job satisfaction among primary health workers by employing mixed methods in a low resource setting. Moreover, the study measures work motivation by considering socio-economic and health system context and by adapting motivational theories. The study limitations include small sample size and heterogeneous nature of health workers that hindered quantitative analysis by professional groups. Also, self-reported bias might have occurred in the responses.

\section{Conclusion}


Age of health workers and satisfaction with career development and financial motivation was significantly associated with job satisfaction among health workers. Additionally, resource availability in health facility, recognition of work and management support is also required to improve job satisfaction. A focus on improving work environment through increased financial motivation and career development opportunities as well as investing in primary health facilities with increased resource support is recommended to improve job satisfaction.

\section{Abbreviations}

AHW: Auxiliary Health Worker; ANM: Auxiliary Nurse Midwife; AOR: Adjusted Odds Ratio; Cl: Confidence Interval; DPHO: District Public Health Office; HPs: Health Posts; HRH: Human Resource for Health; LMICs: Low and Middle Income Countries; MCHW: Maternal and Child Health Worker; MoHP: Ministry of Health and Population; PHCs: Primary Health Centers; SD: Standard Deviation; SEAR: South East Asia Region; TSLC: Technical School Leaving Certificate; VHW: Village Health Worker

\section{Declarations}

\section{Ethics approval and consent to participate}

Ethical approval for this study was provided by the Institutional Review Committee of Institute of Medicine, Tribhuvan University (Registration number: 159/2016).

\section{Consent for publication}

A written informed consent was obtained from individual participants. Confidentiality and anonymity of the participants were ensured by coding the interviews.

\section{Availability of data and materials}

All relevant data are within the manuscript.

\section{Competing interests}

The authors declare that they have no competing interests.

\section{Funding}

The authors received no specific funding for this work.

\section{Author's contribution}

PK conceived the study, conducted the survey and wrote the first draft of the manuscript. BPC and SO provided academic supervision of the study and made critical revisions on the manuscript. PA supported 
in data analysis and reviewing the manuscript. All the authors reviewed, read and finalized the manuscript.

\section{Acknowledgements}

The authors are grateful to the study participants. We would like to acknowledge the District Public Health Office, Jhapa for the permission to conduct the study and the required administrative and logistic support.

\section{References}

1. World Health Organization: Monitoring the building blocks of health systems: a handbook of indicators and their measurement strategies: World Health Organization Geneva, Switzerland; 2010.

2. Dussault G, Dubois C-A: Human resources for health policies: a critical component in health policies. Human resources for health 2003, 1(1):1.

3. Bangdiwala SI, Osegbeaghe Okoye MBBS M: Workforce resources for health in developing countries. Public Health Reviews 2010, 32(1):296.

4. Dieleman M, Harnmeijer JW: Improving health worker performance: in search of promising practices. Geneva: World Health Organization 2006:5-34.

5. Dolea C, Adams 0: Motivation of health care workers-review of theories and empirical evidence. 2005.

6. Willis-Shattuck M, Bidwell P, Thomas S, Wyness L, Blaauw D, Ditlopo P: Motivation and retention of health workers in developing countries: a systematic review. BMC health services research 2008 , 8(1):247.

7. Henderson LN, Tulloch J: Incentives for retaining and motivating health workers in Pacific and Asian countries. Human resources for health 2008, 6(1):18.

8. Mutale W, Ayles H, Bond V, Mwanamwenge MT, Balabanova D: Measuring health workers' motivation in rural health facilities: baseline results from three study districts in Zambia. Hum Resour Health 2013, 11(8):10.1186.

9. Bonenberger M, Aikins M, Akweongo P, Wyss K: The effects of health worker motivation and job satisfaction on turnover intention in Ghana: a cross-sectional study. Hum Resour Health 2014, 12(43):10.1186.

10. World Health Organization: Working together for health: the world health report. Geneva: World Health Organization 2006.

11. MoH/NHSSP: Human Resource For Health Nepal Country Profile In. Kathmandu: Ministry of Health; 2013.

12. Ministry of Health and Population: Annual Report 2017/18. In. Edited by Services DoH. Kathmandu: MoHP; 2018. 
13. DoHS/MoH: Operating Manual of Department of Health Services. In. Kathmandu: Ministry of Health; 2011.

14. Thapa R, Bam K, Tiwari P, Sinha TK, Dahal S: Implementing federalism in the health system of Nepal: opportunities and challenges. International journal of health policy and management 2019, 8(4):195.

15. SOLID Nepal: Barriers to Effective Policy Implementation and Management of Human Resources for Health in Nepal:Health Workforce Performance and Accountability. In. Lalitpur, Nepal: SOLID Nepal; 2012.

16. Dieleman M, Toonen J, Touré $H$, Martineau $\mathrm{T}$ : The match between motivation and performance management of health sector workers in Mali. Hum Resour Health 2006, 4(2):00035-00033.

17. Central Bureau of Statistics: National Population and Housing Census 2011. In. Kathmandu; 2012.

18. Pardee RL: Motivation Theories of Maslow, Herzberg, McGregor \& McClelland. A Literature Review of Selected Theories Dealing with Job Satisfaction and Motivation. 1990.

19. Dartey-Baah K, Amoako GK: Application of Frederick Herzberg's Two-Factor theory in assessing and understanding employee motivation at work: a Ghanaian Perspective. European Journal of Business and Management 2011, 3(9):1-8.

20. Riley S: Herzberg's two-factor theory of motivation applied to the motivational techniques within financial institutions. 2005.

21. Li L, Hu H, Zhou H, He C, Fan L, Liu X, Zhang Z, Li H, Sun T: Work stress, work motivation and their effects on job satisfaction in community health workers: a cross-sectional survey in China. BMJ Open 2014, 4(6):e004897.

22. Tavakol M, Dennick R: Making sense of Cronbach's alpha. International journal of medical education 2011, 2:53.

23. Mbindyo P, Gilson L, Blaauw D, English M: Contextual influences on health worker motivation in district hospitals in Kenya. Implement Sci 2009, 4(1):43.

24. Deriba BK, Sinke SO, Ereso BM, Badacho AS: Health professionals' job satisfaction and associated factors at public health centers in West Ethiopia. Human Resources for Health 2017, 15(1):36.

25. Mafini C, Dlodlo N: The relationship between extrinsic motivation, job satisfaction and life satisfaction amongst employees in a public organisation. SA Journal of Industrial Psychology 2014, 40(1):01-12.

26. Ghimire J, Kumal A, Mahato R, Gupta R: Factors Associated with the Motivation and De-motivation of Health Workforce in Nepal. Journal of Nepal Health Research Council 2013.

27. SOLID Nepal: Barriers to Effective Policy Implementation and Management of Human Resources for Health in Nepal: Human Resources for Health Management from Central to District Level. In. Lalitpur, Nepal; 2012.

28. MoH/NSI: Measuring the Quality of Rural Based Government Mid-level Health Care Workers. In. Kathmandu: Nick Simons Institute 2007. 
29. Peters DH, Chakraborty S, Mahapatra P, Steinhardt L: Job satisfaction and motivation of health workers in public and private sectors: cross-sectional analysis from two Indian states. Human Resources for Health 2010, 8(1):27.

30. Kumar R, Ahmed J, Shaikh BT, Hafeez R, Hafeez A: Job satisfaction among public health professionals working in public sector: a cross sectional study from Pakistan. Human Resources for Health 2013, 11(1):2.

31. Lambrou P, Kontodimopoulos N, Niakas D: Motivation and job satisfaction among medical and nursing staff in a Cyprus public general hospital. Hum Resour Health 2010, 8(1):26-34.

32. Geleto A, Baraki N, Atomsa GE, Dessie Y: Job satisfaction and associated factors among health care providers at public health institutions in Harari region, eastern Ethiopia: a cross-sectional study. $B M C$ research notes 2015, 8(1):394.

33. Blaauw D, Ditlopo P, Maseko F, Chirwa M, Mwisongo A, Bidwell P, Thomas S, Normand C: Comparing the job satisfaction and intention to leave of different categories of health workers in Tanzania, Malawi, and South Africa. Glob Health Action 2013, 6:19287.

34. Zimmerman M, Shakya R, Pokhrel BM, Eyal N, Rijal BP, Shrestha RN, Sayami A: Medical students' characteristics as predictors of career practice location: retrospective cohort study tracking graduates of Nepal's first medical college. bmj 2012, 345:e4826.

35. Sapkota TN, van Teijlingen E, Simkhada PP: Nepalese health workers' migration to the United Kingdom: A qualitative study. Health Science Journal 2014, 8(1).

36. Minsitry of Health and Population: National Health Policy 2019. In. Kathmandu: MoHP; 2019.

37. Bhusal C, Singh S, Aryal K, Jha B, Ghimire N, Shah N, Khatiwada D, Magar A: Assessment of district health system within inter-sectoral context in Nepal. Journal of Nepal Health Research Council 2013, 11(24):163-176.

38. Bhandari Baral B, Prajapati R, Karki K: Distribution and Skill Mix of Health Workforce in Nepal. Journal of Nepal Health Research Council 2013.

39. Mkoka DA, Mahiti GR, Kiwara A, Mwangu M, Goicolea I, Hurtig A-K: "Once the government employs you, it forgets you": Health workers' and managers' perspectives on factors influencing working conditions for provision of maternal health care services in a rural district of Tanzania. Human resources for health 2015, 13(1):77.

40. Magar A: Human Resource for Health in Nepal. Journal of Nepal Health Research Council 2013.

41. Khanal $P$, Mishra SR: Federal governance and the undying parade for universal health coverage in Nepal. Health Prospect 2019, 18(1):1-3. 